\section{Preliminary study on the inactivation of anisakid larvae in baccalà prepared according to traditional methods}

\author{
Giorgio Smaldone, ${ }^{1,2}$ Raffaele Marrone, \\ Giuseppe Palma, ${ }^{3}$ Paolo Sarnelli, ${ }^{2}$ \\ Aniello Anastasio ${ }^{1,2}$ \\ ${ }^{1}$ Department of Veterinary Medicine and \\ Animal Production, University of Naples \\ Federico II; ${ }^{2}$ Centro di Riferimento \\ Regionale per la Sicurezza Sanitaria del \\ Pescato (CRiSSaP) - Campania; \\ ${ }^{3}$ Assoittica Italia, Italy
}

\begin{abstract}
The European Food Safety Authority stated that many traditional marinating and cold smoking methods are not sufficient to kill A. simplex and asked to evaluate alternative treatments for killing viable parasites in fishery. Baccalà is a well-liked traditional product. The aim of study was to evaluate the effectiveness of the salting process on the inactivation of nematodes of the genus Anisakis in naturally infected Baccalà fillets. N. 19 fillets, subjected to a dual salting process (brine and dry salting) were analyzed. Visual inspection and chloropeptic digestion were performed. Larvae viability was evaluated, and parameters such as $\mathrm{NaCl}$ $(\%)$, moisture (\%), WPS and $\mathrm{a}_{\mathrm{w}}$ were determined. In n. 17 samples parasites were found 123 parasites with a mean intensity of $7.23 \pm 4.78$ and an mean abundance of $6.47 \pm 5.05$. Visual examination has revealed 109 parasites. $61.8 \%$ of larvae were found in the ventral portions. The results show that salting process with a salt concentration of $18.6 \%, a_{w}$ values of 0.7514 and $24.15 \%$ WPS in all parts of baccalà fillets, devitalise Anisakidae larvae in a 15-day period.
\end{abstract}

\section{Introduction}

Salt-curing of fish have been used as preservation methods since ancient times; even if this method have lost importance for preservation purposes, due to the widespread use of new technologies in developed countries, salted cod (Gadus $s p p$ ), is one of the main heavy-salted products consumed in Mediterranean countries. Salted cod, named bacalhau in Portugal or baccalà in Italy, is highly appreciated because of its characteristic taste and nutri- tional quality (Beraquet et al., 1975; Bjørkevoll et al., 2003; Heredia et al., 2007; Lauritzsen et al., 2004; Martìnez-Alvarez et al., 2005). Baccalà is considered a shelf stable product (low moisture and high salt content). Regarding parasites, Atlantic cod has an exceptionally rich and varied parasite fauna (Pseudoterranova spp, Anisakis spp, and others) compared with most other species of marine fish (Hemmingsen and MacKenzie, 2001). This may be due to its eating habits and to the fishing area rich of definitive hosts (Cipriani et al., 2015). Parasitic nematodes are a problem in cod processing industries (Margeirsson et al., 2007) because when are present in the cod flesh were considered the worst defects and contribute to an unpleasant appearance. On the other hand, baccalà is still consumed raw (marinated dish such as carpaccio) or semi-raw (partly cooked), which could represent a threat to human health. Thus, immediate removal of the viscera (gutting) after catching is fundamental to reduce the number of parasites in cod flesh (Rodrigues, 2006). Human anisakidosis, caused by parasites of the Anisakidae family, the most important fish parasites from a sanitary point of view, is associated with the consumption of raw or almost raw seafood products in which are present viable parasites. The European Food Safety Authority (EFSA, 2010) reported approximately 20000 anisakiasis cases worldwide prior to 2010, with $>90 \%$ from Japan. Reg. EC 853/04 (Reg. EC 853/04; European Commission, 2004) states that fishery products to be consumed raw or almost raw and fishery products marinated and/or salted require freezing $\left(-20^{\circ}\right.$ for $24 \mathrm{~h}$ or $-35^{\circ}$ for 15 h) if the ripening process is insufficient to kill nematode larvae.

Since freezing can affect the sensorial characteristics of salted fishery products (Stefànsson et al., 2000), several alternative methods were studied in order to obtain an equivalent effect (Adams et al., 1999; Anastasio et al., 2016; Giarratana et al., 2015). Aim of the study was to evaluate the effectiveness of the salting process on the inactivation of nematodes of the genus Anisakis in naturally infected Baccalà fillets.

\section{Materials and Methods}

\section{Sampling}

N. 19 samples of baccalà fillets (Gadus morhua - FAO area 27) belonging to the same lot with different weight categories (300-500 g; 500-800 g; 800-1200 g) were
Correspondence: Raffaele Marrone, Department of Veterinary Medicine and Animal Production, University of Naples Federico II, 80137 Naples, Italy.

Tel: +39.081 .2536464$

E-mail: raffaele.marrone@unina.it

Key words: Anisakis; EFSA; Baccalà.

Contributions: GS and AA designed the overall study. GS and RM performed Anisakis inspection in fishery products. AA and GS analysed the results and drafted the paper. AA, PS and GP contributed to the ideas behind the study and the writing of the paper. All authors critically reviewed the paper and agreed the final content of the version to be published.

Conflict of interest: the authors declare no potential conflict of interest.

Received for publication: 28 July 2017.

Revision received: 25 October 2017.

Accepted for publication: 25 October 2017.

This work is licensed under a Creative Commons Attribution-NonCommercial 4.0 International License (CC BY-NC 4.0).

(C) Copyright G. Smaldone et al., 2017

Licensee PAGEPress, Italy

Italian Journal of Food Safety 2017; 6:6964

doi:10.4081/ijfs.2017.6964

chosen for trial. Fillets were subjected to a double salting process: in Faroe Islands fresh cod fillets were pickle salted in a $\mathrm{NaCl}$ brine solution $(13 \%)$ at $5^{\circ} \mathrm{C}$ for $24 \mathrm{~h}$ in a $1: 1$ fish-to-brine ratio; afterwards, in a food company located in Naples (Campania, Italy), fillets were dry salted and matured for 3 months at $5^{\circ} \mathrm{C}$ by stacking fish and salt (weight ratio 1:1) in alternating layers.

Every 15 days, until the $90^{\text {th }}$ day, n. 3 fillets belonging to the 3 different weight category were sampled and delivered to the Food Chemistry laboratory of the Department of Veterinary Medicine and Animal Production, University of Naples Federico II for analytic determination.

\section{Physical-chemical analyses}

The following determinations were performed, except $\mathrm{pH}$, on pooled samples: $\mathrm{pH}$ was measured with a digital $\mathrm{pH}$-meter (CrisonMicroTT 2022, Crison Instruments, Barcelona); $\mathrm{a}_{\mathrm{w}}$ was measured by Aqualab 4 TE (Decagon Devices Inc., USA); Moisture (\%) was determined by oven drying for 24 $\mathrm{h}$ at $105^{\circ} \mathrm{C}(\mathrm{AOAC}, 1990)$. Water phase salt (WPS) was determined according to Kenneth and Hilderbrand (1991). The salt content $(\% \mathrm{NaCl})$ was measured with the Volhard method (AOAC, 2000). All tests were done in duplicate. 


\section{Parasitological survey}

Each sample was first skinned, desalted in water for $2 \mathrm{~h}$ and separated into the hypaxial (ventral) and epaxial (dorsal) regions, following the horizontal septum. According to Reg. EC 2074/05 (Reg EC 2074/05; European Commission, 2005) each portion was subjected to a visual inspection; afterwards, each part was digested separately in a chloropeptic solution, according to Llarena-Reino et al. (2013). All anisakid larvae were identified at the genus level by microscopic examination of diagnostic characters (Mattiucci et al., 2011). Infection indexes were established according to Bush et al. (1997).

\section{Larvae viability}

At each sampling time, to test viability, all larvae collected from fillets were put into a pepsin digestion solution $(0.5 \% \mathrm{w} / \mathrm{v}$ Pepsin in $0.063 \mathrm{M} \mathrm{HCl}$ ) and inspected under a stereomicroscope at $37^{\circ} \mathrm{C}$ for one hour (CODEX, 2004). Viability scores were assigned according to Hirasa and Takemasa (1998): viable, score 3; motility reduction, score 2 ; motility only after stimulation by a needle, score 1 ; and death, score 0 , when no motility was observed.

\section{Results}

\section{Physical-chemical analyses}

$\mathrm{PH}, \mathrm{a}_{\mathrm{w}}, \mathrm{NaCl}(\%)$, moisture (\%) and WPS (\%) contents are shown in Table 1. $\mathrm{PH}, \mathrm{a}_{\mathrm{w}}$ and moisture values remained constant until the $90^{\text {th }}$ day of curing. Salt content ranged from 18.6 and $21.4 \%$; WPS ranged from 24.15 to 26.55 . Moisture content and WPS were typical of a ripened and shelf stable product (FDA, 2011).

\section{Infection indexes}

In $\mathrm{n} .17$ fillets were found parasites: a total of 123 Anisakidae larvae (prevalence $89.47 \%$ ) were detected; n. 109 larvae were detected by visual inspection $(88.61 \%)$. Chloropeptic digestion has revealed n. 14 parasites. The mean \pm SD larva abundance and the mean $\pm \mathrm{SD}$ larva intensity were $6.47 \pm 5.05$ and $7.23 \pm 4.78$, respectively. All larvae were identified as belonging to the genus Anisakis $(80.49 \%)$ and Pseudoterranova (19.51\%) by their morphological characters. A positive correlation between the size and the number of parasites was noted: infact fillets belonging to weight category $300-500 \mathrm{~g}$ had a mean parasite abundance \pm SD of $4.4 \pm 4.47$; fillets belonging to weight category $500-800 \mathrm{~g}$ had a mean parasite abundance \pm SD of $7 \pm 2.94$; fillets belonging to weight category 800 $1200 \mathrm{~g}$ had a mean parasite abundance \pm SD of $10.2 \pm 5.76$; smaller weight samples showed a deeper larvae encystation. $61.8 \%$ of larvae were found in the ventral portions (Figure 1).

\section{Larvae viability}

Salt killing effect was evaluated every 15 days: at the first sampling time all tested larvae probed with a dissection needle or with a nipper did not show any movement, and were considered dead (score 0 ). Furthermore at every sampling time until the $90^{\text {th }}$ day of the ripening process, all tested larvae were dead.

\section{Discussion}

According to Codex Alimentarius, potential hazards in fish and fishery pro- ducts during filleting, skinning, trimming and candling are viable parasites, while parasites are only potential defects. Codex Alimentarius also states that brining or pickling may reduce the parasite hazard if the products are kept in an adequate combination of salt content and curing time (CAC/RCP 52-2003).

The results of this study show that salting process of cod with a salt concentration of $18.6 \%$ for at least 15 days, which is considered the minimum time required in order to obtain commercial salted cod (Andrés et al., 2005), devitalise all anisakidae larvae present in flash. The salting process causes osmotic damages to cuticle and digestive tract modifying permeability of the membrane with a leakage of cell content such as ions (Bakkali et al., 2008). Previous studies reported the ability of salt to inactivate

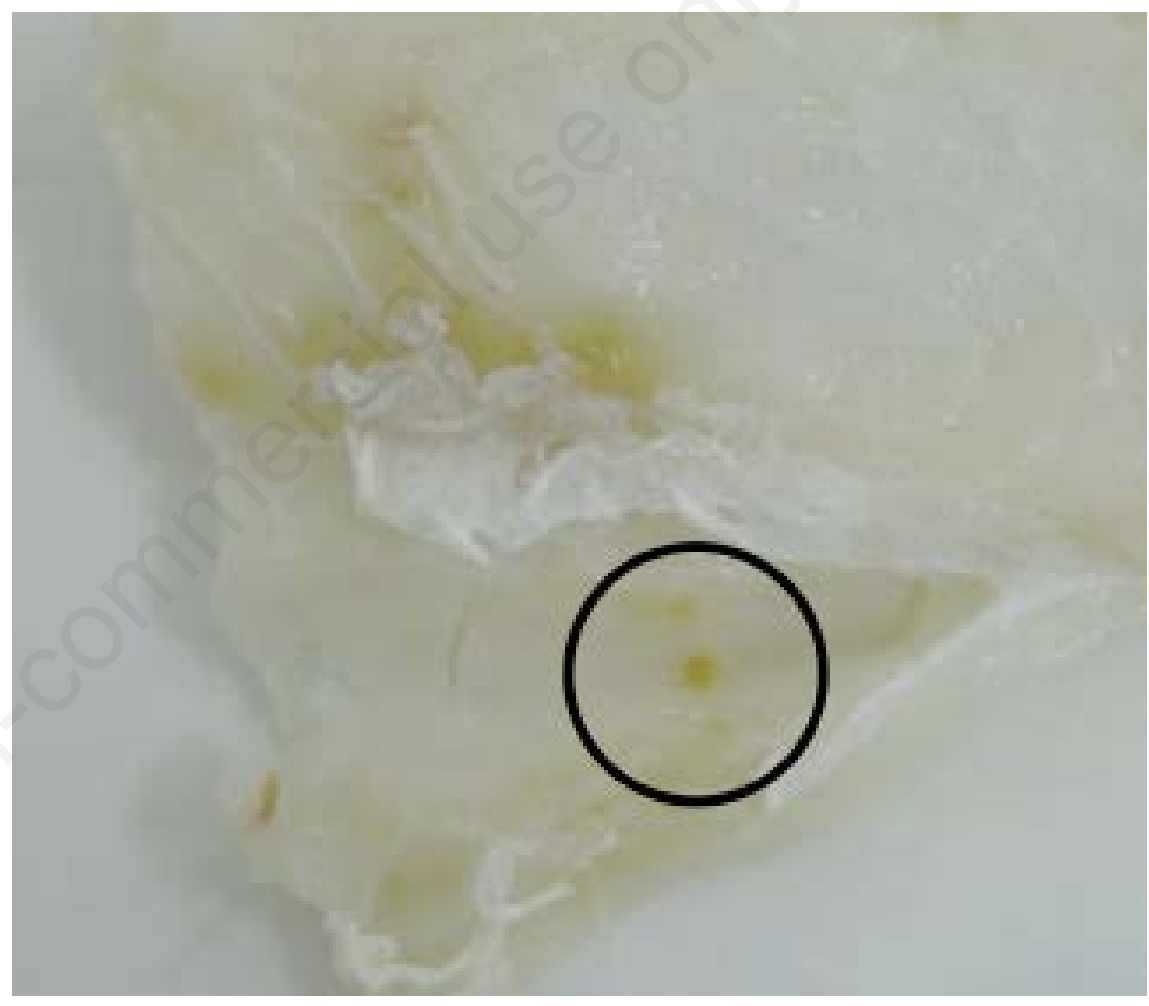

Figure 1. Baccalà belly flap with encysted anisakidae larvae.

Table 1. Trend of $\mathrm{pH}$, aw, $\mathrm{NaCl}(\%)$, moisture (\%) and water phase salt (\%) contents in baccalà during the ripening process.

\begin{tabular}{|c|c|c|c|c|c|c|}
\hline \multirow{2}{*}{ Variables } & \multicolumn{5}{|c|}{ Ripening days } & \multirow[b]{2}{*}{90} \\
\hline & 15 & 30 & 45 & 60 & 75 & \\
\hline aw & 0.7514 & 0.7403 & 0.7401 & 0.7395 & 0.7388 & 0.7381 \\
\hline $\mathrm{pH}$ & 6.21 & 6.22 & 6.18 & 6.2 & 6.15 & 6.15 \\
\hline $\mathrm{NaCl}$ & 18.6 & 20.7 & 20.9 & 20.9 & 21.3 & 21.4 \\
\hline Moisture & 58.4 & 58.7 & 58.7 & 59 & 59.1 & 59.1 \\
\hline WPS & 24.15 & 26.07 & 26.25 & 26.15 & 26.49 & 26.55 \\
\hline
\end{tabular}

WPS, water phase salt. 
nematodes. Wootten and Cann (2001) showed that brining with $21 \%$ salt for 10 days killed all Anisakis larvae. Regarding salted cod, Rodrigues (2006) proved that number of parasites in salted cod was generally lower than in fresh cod because of gutting, visual inspection during filleting, manipulation and removal of the parasites that are located superficially on visceral peritoneum; moreover he stated that a curing period by salting of 13 days is enough to devitalise parasites.

Anastasio (2016) showed that the dry salting process of anchovies with a salt concentration of $21 \%$ in all the edible parts, for at least 15 days, kill Anisakis pegreffii larvae present in ripened anchovies.

In Spain the Agencia Española de Seguridad Alimentaria y Nutrición (AESAN, 2007) have specified the technical salting parameters and curing period, excluding freezing of products, able to inactivate anisakidae larvae: when salt concentration in fish is above $9 \%$ for at least six weeks, between $10 \%$ and $20 \%$ for at least four weeks, or more than $20 \%$ for at least three weeks freezing of fish products can be avoided.

\section{Conclusions}

EFSA asked to evaluate alternative treatments for killing viable parasites in fishery which could preserve traditional production methods ensuring food safety and product quality. The results of our study show that for baccalà a salting period of 15 days with a $18.6 \% \mathrm{NaCl}$ concentration, combined with $\mathrm{a}_{\mathrm{w}}$ and WPS values of 0.7514 and $24.15 \%$, is effective to inactivate anisakidae larvae present in the fillets. This result might have practical outcomes because freezing treatment, at this time mandatory for EC, may adversely affect organoleptic features of salted fish products (Stefànsson et al., 2000).

\section{References}

Adams AM, Miller KS, Wekell MM, Dong FM, 1999. Survival of Anisakis simplex in microwave-processed arrow tooth flounder. J Food Protect 4:403-9.

AESAN, 2007. Informe del Comitate Científico de la Agencia Española de Seguridad Alimentaria y Nutriciòn (AESAN) sobre medidas para reducir el riesgo asociado a la presencia de Anisakis.

Andrés A, Rodrìguez-Barona $\mathrm{S}$, Barat JM, Fito P, 2005. Salted cod manufacturing: influence of salting procedure on process yield and product characteristics. J Food Eng 69:467-71.

Anastasio A, Smaldone G, Cacace D, Marrone R, Lo Voi A, Santoro M, Cringoli G, Pozio E, 2016. Inactivation of Anisakis pegreffii larvae in anchovies (Engraulis encrasicolus) by salting and quality assessment of finished product. Food Control 64:115-9.

AOAC, 2000. Official Methods of Analysis, 17th ed. Method 976.18. Association of Official Analytical Chemists, Gaithersburg, MD, USA.

AOAC, 1990. Official Methods of Analysis, 15th ed. Method 950.46, 11, 931. Association of Official Analytical Chemists, Arlington, VA, USA.

Bakkali F, Averbeck S, Averbeck D, Idaomar M, 2008. Biological effects of essential oils - a review. Food Chem Toxicol 46:446-75.

Beraquet JN, Okada M, Ferreira VL, Menezes $\mathrm{HC}, 1975$. Um processo ràpido de salga e secagem de peixe. I. Aspectos de processamento e aceitabilidade. Coletânea do Instituto de Tecnologia de Alimentos 6:37-49.

Bjørkevoll I, Olsen RL, Skjerdal OT, 2003. Origin and spoilage potential of the microbiota dominating genus Psychrobacter in sterile rehydrated saltcured and dried salt-cured cod (Gadus morhua). Intl J Food Microbiol 84:17587.

Bush, AO, Lafferty KD, Lotz JM, Shostak AW, 1997. Parasitology meets ecology on its own terms: Margolis et al. revisited. J Parasitol 83:575-83.

CAC/RCP 52-2003, 2003. Code of practice for fish and fishery products. Available from: ftp://ftp.fao.org/docrep/fao/ 011/a1553e/a1553e00.pdf

Cipriani P, Smaldone G, Acerra V, D'Angelo L, Anastasio A, Bellisario B, Palma G, Nascetti G, Mattiucci S, 2015. Genetic identification and distribution of the parasitic larvae of Anisakis pegreffii and Anisakis simplex (s.s.) in European hake Merluccius merluccius from the Tyrrhenian Sea and Spanish Atlantic coast: implications for food safety. Int J Food Microbiol 198:1-8.

CODEX, 2004. Standard for salted Atlantic herring and salted sprat. CODEX STAN 244e2004. Available from: http://www. fao.org/fao-who-codexalimentarius/shproxy/ru/?lnk $=\quad 1 \&$ url $=$ https $\% 2$ $53 \mathrm{~A} \% 252 \mathrm{~F} \% 252 \mathrm{Fw}$ orkspace.fao.org\% 252Fsites\%252Fcodex\%252FStandards $\% 252$ FCODEX\%2BSTAN\%2B2442004\%252 FCXS_244e.pdf

EFSA, 2010. Scientific opinion on risk assessment of parasites in fishery prod- ucts. EFSA J 8:1543.

European Commission, 2004. Reg. EC 853/04. Regulation (EC) 853/2004, laying down specific hygiene rules for food of animal origin and Regulation (EC) 854/2004 laying down specific rules for the organization of official controls on products of animal origin intended for human consumption. Commision to the Council and the European Parliament.

European Commission, 2005. Reg. EC 2074/05. Commission Regulation (EC) No 2074/2005 (EC 853/2004 rev) of 5 December, 2005 laying down implementing measures for certain products under Regulation (EC) No 853/2004, Regulation (EC) No 854/2004 and Regulation (EC) No 882/2004, derogating from Regulation (EC) No 852/2004 and amending Regulations (EC) No $853 / 2004$ and (EC) No 854/2004, Official Journal of the European Union.

FDA, 2011. Food and drug administration. Fish and Fisheries products hazards and controls guidance (4th ed.). Available from: https://www.fda.gov/ downloads/food/guidanceregulation/ucm 25197 $0 . p d f$

Giarratana F, Panebianco F, Muscolino D, Beninati C, Ziino G, Giuffrida A, 2015. Effect of allyl isothiocyanate against Anisakis larvae during the anchovy marinating process. J Food Protect 78: 767-71.

Hemmingsen W, MacKenzie K, 2001. The parasite fauna of the atlantic cod, Gadus morhua L. Adv Mar Biol 40:1-80.

Heredia A, Andrés A, Betoret N, Fito P, 2007. Application of the SAFES (systematic approach of food engineering systems) methodology to salting, drying and desalting of cod. J Food Eng 83:267-76.

Hirasa K, Takemasa M, 1998. Spice sciences and technology. Dekker, New York, NY, USA.

Kenneth S, Hilderbrand Jr, 1991. Quick determination of water phase salt content of smoked fish. In: Oregon State University extension service, special report 883 (Oregon State University. Agricultural Experiment station) Corvallis, OR, USA.

Lauritzsen K, Akse L, Johansen A, Joensen S, Sørensen NK, Olsen RL, 2004. Physical and quality attributes of salted cod (Gadus morhua L.) as affected by the state of rigor and freezing prior to salting. Food Res Intl 37:677-88.

Llarena-Reino M, Piñeiro C, Antonio J, Outeiriño L, Vello C, González ÁF, Pascual S, 2013. Optimization of the pepsin digestion method for anisakids 
inspection in the fishing industry. Vet Parasitol 191:276-83.

Martìnez-Alvarez $\mathrm{O}$, Borderìas $\mathrm{J}$, GòmezGuillén MC, 2005. Use of hydrogen peroxide and carbonate/bicarbonate buffer for soaking of bacalao (salted cod). Eur Food Res Technol 221:22631.

Margeirsson S, Guðmundur RJ, Arason S, Thorkelsson G, 2007. Influencing factors on yield, gaping, bruises and nematodes in cod (Gadus morhua) fillets. J Food Eng 80:503-8.
Mattiucci S, Paoletti M, Borrini F, Palumbo M, Macarone-Palmieri R, Gomes V, Casati A, Nascetti G, 2011. First molecular identification of the zoonotic parasite Anisakis pegreffii (Nematoda: Anisakidae) in a paraffin-embedded granuloma taken from a case of human intestinal anisakiasis in Italy. BMC Infect Dis 11:82.

Rodrigues MJ. 2006. Estudos de qualidade em bacalhau. PhD Thesis. Abel Salazar Biomedical Sciences Institute, University of Porto, Portugal.
Stefànsson G, Nielsen HH, Skara T, Schubring R, Oehlenschlager J, Luten J, Derrick S, Gudmundsdóttir G, 2000. Frozen herring as raw material for spice-salting. J Sci Food Agr 80:131924.

Wootten R, Cann DC, 2001. Round worms in fish. Torry Advisory Note No. 80, Torry Research Station. UK Ministry of Agriculture, Fisheries and Food. Available from: http://www.fao.org/ wairdocs $/ \tan / x 5951 \mathrm{e} / \mathrm{x} 5951 \mathrm{e} 00 . \mathrm{HTM}$ 